\title{
A ideia da natureza como patrimônio: um percurso histórico ${ }^{1}$ The idea of nature as a public asset: a walk through history
}

\author{
Cynthia RONCAGLIO*
}

\begin{abstract}
RESUMO
O artigo estabelece conexões históricas entre algumas representações sociais da natureza que se esboçam no e sobre o Brasil e que permitem vislumbrar como, ao longo do tempo, constrói-se a ideia da natureza como um bem patrimonial. Para tanto, discute as diversas descobertas do Brasil como nação e as tentativas, contrárias e contraditórias, do poder público e dos seus representantes de proteger a natureza e dar a ela um status de patrimônio. Embora alguns conservacionistas tenham tentado superar uma ótica utilitarista e antropocêntrica sobre a natureza, foi esta que prevaleceu na política patrimonial brasileira.
\end{abstract}

Palavras-chave: natureza e sociedade; representações sociais; patrimônio natural.

\begin{abstract}
The article establishes historical connections between some social representations of nature existing in and about Brazil that allows us to see, over time, how the idea of nature as common heritage was construed. For such, it discusses the various discoveries of Brazil as a nation and the attempts, contrary and contradictory, of the public authorities and their representatives to protect nature and to give it the status of public asset. Even though some conservationists have tried to overcome a utilitarian and anthropocentric view of nature, this is what has prevailed in Brazilian public policy.
\end{abstract}

Key-words: nature and society; social representations; natural patrimony.

\section{Introdução}

As representações da natureza em diversas sociedades incluem um vasto repertório de experiências e valores materiais, espirituais, morais e éticos forjados ao longo da sua construção histórica como sociedades e como nações. A partir do século XVIII, as nações estabelecidas em várias partes do mundo construíram suas memórias e identidades, dentre outros aspectos, a partir da dominação de um território - suas percepções acerca dos desafios enfrentados para dominar uma região inóspita ou obter vantagens das condições naturais, dos limites de exploração impostos pela própria natureza ou pela cultura, das ações humanas modificadoras do ambiente.

\footnotetext{
* Doutora em Meio Ambiente e Desenvolvimento pela UFPR e Professora do Curso de Arquivologia, do Departamento de Ciência da Informação e Documentação da Universidade de Brasília; cynthiar@unb.br.

${ }^{1}$ Parte deste texto surgiu de reflexões apresentadas originalmente na minha tese apresentada ao Curso de Doutorado em Meio Ambiente e Desenvolvimento da Universidade Federal do Paraná, sob o título Emblema do patrimônio natural no Brasil: a natureza como artefato cultural, defendida em 2007.
} 
A pluralidade de concepções sobre a natureza, no entanto, não se evidencia tão-somente entre nações forjadas ao longo dos últimos trezentos anos, mas ela ocorre mesmo em um único território, visto que os modos como os indivíduos e grupos sociais se apropriam da realidade e constroem suas percepções estão relacionados a um conjunto de significações decorrentes da classe social a que pertencem, sua formação e atividade profissional, seu poder de decisão e intervenções no meio físico-material, aos interesses e às finalidades que, no tempo e no espaço, influenciam seu contato e relação com a natureza.

Um sobrevoo pela ideia de natureza no Brasil, ou melhor, das múltiplas concepções de natureza que vêm sendo construídas ao longo da sua história, possibilita certa compreensão do modo como se constituiu a ideia do patrimônio natural nacional e as ações conflitantes e contraditórias que envolvem a preservação desse patrimônio. Certamente as características naturais, étnicas e sociais de cada região do Brasil podem expressar variadas, significativas e divergentes concepções de natureza da sociedade brasileira. Não é o foco deste artigo, entretanto, identificar e reconhecer as especificidades dessas concepções, que demandariam um amplo e aprofundado estudo comparativo regional. Tampouco, trata-se de uma tentativa, em geral malfadada e ingênua, de sintetizar, em poucas páginas, mais de 500 anos de história da concepção de natureza no Brasil. Pretende-se, de outro modo, e em dimensões bem mais modestas, destacar algumas representações gerais da natureza forjadas por certos segmentos das sociedades europeias e brasileira, em determinados contextos históricos, numa perspectiva evolutiva, mas não-linear, que confluíram para a formação e o desenvolvimento de discursos e práticas oficiais sobre a preservação da natureza.

Trata-se, ainda, de identificar alguns paradoxos da realidade brasileira que, como afirma DaMatta (1997), caracterizam o "dilema brasileiro" e podem ser aplicados às representações da natureza: ao mesmo tempo em que o Brasil, para fazer parte do concerto das nações civilizadas, incorpora no final do século XIX os princípios e valores da modernidade tal como o individualismo igualitário, a justiça social, o progresso material e o controle da natureza, persistem na sua estrutura e práticas sociais os traços da ideologia tradicional que fundou a sociedade brasileira como o clientelismo, o nepotismo, a corrupção e a exploração descontrolada dos recursos naturais.

\section{A descoberta portuguesa: visão paradisíaca das terras é águas infinitas}

Como ponto de partida para a análise de uma forte concepção de natureza que prevalece até hoje na mente de qualquer brasileiro - a ideia de uma natureza abundante, exuberante, repleta das mais variadas espécies vegetais e animais, de riquezas naturais que parecem não ter fim -, toma-se como referência o que hoje já é praticamente um mito de fundação da sociedade brasileira: a célebre carta de Pero Vaz de Caminha, enviada ao rei D. Manuel, em $1 .^{\circ}$ de maio de 1500 , relatando a notícia do achamento (termo português inclusive mais adequado do que o termo "descoberta" já que outros homens ou povos já haviam descoberto o território anteriormente) das novas terras e descrevendo minuciosamente o contato com plantas, animais e inocentes habitantes da terra que andavam nus, sem a preocupação de esconder as suas vergonhas e que viriam a ser denominados genericamente de índios pelos "desorientados" navegadores lusitanos que pensavam estar chegando às Índias.

O documento oficial, que ganhou notoriedade em relação a outros tantos que foram enviados pelos demais membros da frota de Cabral, dando notícias sobre o sucesso da expedição, simboliza uma percepção da natureza, marcada por uma visão edênica de uma sociedade que busca a riqueza além-mar e encontra o Paraíso Terrestre, como ilustra esse pequeno trecho:

[...] Esta terra, Senhor, parece-me que, da ponta que mais contra o sul vimos, até à outra ponta que contra o norte vem, de que nós deste porto houvemos vista, será tamanha que haverá nela bem vinte ou vinte e cinco léguas de costa. Traz ao longo do mar em algumas partes grandes barreiras, umas vermelhas, e outras brancas; e a terra de cima toda chã e muito cheia de grandes arvoredos. De ponta a ponta é toda praia... muito chã e muito formosa. Pelo sertão nos pareceu, vista do mar, muito grande; porque a estender olhos, não podíamos ver senão terra e arvoredos -- terra que nos parecia muito extensa. Até agora não pudemos saber se há ouro ou prata nela, ou outra coisa de metal, ou ferro; nem lha vimos [grifo meu]. Contudo a terra em si é de muito bons ares frescos e temperados como os de EntreDouro-e-Minho, porque neste tempo d'agora assim os achávamos como os de lá. Águas são muitas; infinitas. 
Em tal maneira é graciosa que, querendo-a aproveitar, dar-se-á nela tudo; por causa das águas que tem! (A CARTA DE PERO VAZ DE CAMINHA, 1963, s.p.)

Mais importante do que conhecer as peculiaridades das novas terras e compreender os valores culturais dos seus habitantes era descobrir se existia ouro e prata, o que não impediu, diante da sobeja natureza e da docilidade e inocência dos seus habitantes, contemplar primeiramente a visão do paraíso. E é esta minuciosa descrição contemplativa da natureza, presente na carta de Caminha, que demonstra a ambiguidade da relação que se estabelece com a natureza desde o princípio: é repleta de poderes mágicos, fonte de diversidade biológica e beleza estonteante; ao mesmo tempo é submetida passivamente aos caprichos e desejos dos homens que a conquistarem. Tal visão combina perfeitamente com o espírito aventureiro que orientou a expansão colonial portuguesa, tão bem analisada por Sérgio Buarque de Holanda no clássico ensaio Raízes do Brasil. Conforme aponta o autor:

O que o português vinha buscar era, sem dúvida, a riqueza, mas riqueza que custa ousadia, não riqueza que custa trabalho. A mesma, em suma, que se tinha acostumado a alcançar na Índia com as especiarias e os metais preciosos. Os lucros que proporcionou de início, o esforço de plantar a cana e fabricar o açúcar para mercados europeus, compensavam abundantemente - efetuado, de resto, com as mãos e os pés dos negros -, mas era preciso que fosse muito simplificado, restringindo-se ao estrito necessário às diferentes operações" (HOLANDA, 1995, p.49).

Ou seja, o caráter aventureiro dos colonizadores ibéricos, em especial, e o princípio de extrair do solo o máximo de benefícios sem grandes sacrifícios - a não ser sacrificando outros homens - marcou a forma da produção agrária brasileira.

\section{Perto da natureza, longe da inocência}

Embora se esteja afirmando aqui, implicitamente, que a exploração predatória da natureza no Brasil se inicia com o processo da expansão colonial portuguesa, voltado unicamente para os interesses econômicos da Metrópole, isto não significa considerar que as nações indígenas que ocupavam o território brasileiro tivessem uma relação de equilíbrio com a natureza e do tipo não predatório. A técnica das queimadas, por exemplo, é uma das mais antigas usadas para limpeza e preparo do solo para plantio e pastagem e a forma mais barata, e também a mais nociva, de executar essa tarefa; causa a infertilidade do solo, a migração ou o desaparecimento de aves, as quais protegem as plantações das "pragas", entre outros fatores. Os indígenas que se dedicavam à agricultura faziam uso das queimadas antes dos colonizadores chegarem.

Como ressalta Drummond (2000), de algum modo todas as populações, em qualquer tempo, que fixam residência por um determinado período, mesmo que numericamente irrisórias e dotadas de tecnologia rudimentar, "alteram o ambiente natural em graus por vezes extensos, profundos e duradouros" ou, em outras palavras, “não há grupamento humano 'inocente' no tocante ao uso dos recursos do ambiente." Giddens (1996) também defende essa tese e rejeita a suposição de que aqueles que vivem mais "perto da natureza", como sociedades de caçadores/ coletores e horticultores, estabeleçam laços mais profundos e de equilíbrio com a natureza do que os modernos. Em alguma medida todas as sociedades experimentam alguma forma de subjugação da natureza e destrutibilidade ambiental, mesmo que depois identifiquem nela uma força benéfica. No entanto, o controle que se exerce sobre a natureza, segundo Giddens, significa que "aquela natureza socializada, por definição, deixa de ser natural; mas isso não é ipso facto o mesmo que causar danos ao meio ambiente" (1996, p.21).

O controle exercido pode ser tanto para cuidar da natureza - e aí faz sentido a ideia de buscar o equilíbrio da relação entre homem e natureza - quanto tratá-la de uma forma instrumental ou indiferente. $\mathrm{O}$ que se pode afirmar com certeza sobre a relação com a natureza no Brasil é que o uso dos recursos naturais só foi levado às últimas consequências, negativas para a natureza e também para sociedade, pelo modo mercantil de apropriação da natureza do sistema colonial mundial e pela crescente pressão sobre os recursos deflagrada pelo aumento populacional, a partir da colonização portuguesa, causando impactos até hoje não suficientemente investigados ou passíveis de o serem² ${ }^{2}$.

${ }^{2}$ Conforme salienta Warren Dean. A ferro e fogo: a história da devastação da mata atlântica brasileira. São Paulo: Companhia das Letras, 1997, p. 366, os naturalistas do século XIX como Saint-Hilaire, Von Martius e Spix já se preocupavam com as possibilidades de extinções de plantas e animais da Mata Atlântica, por exemplo. 
A imbricação entre sociedade e natureza é tão forte e a ideologia do enriquecimento fácil é tão disseminada, baseada na compulsiva exploração dos frutos que a terra generosa oferece, sem se preocupar com alguma forma de interação, que a própria História do Brasil será contada a partir dos "ciclos" de descoberta, exploração e esgotamento das fontes naturais. Assim, a sociedade brasileira, guiada pela natureza, se constituirá de modo quase espontâneo, sucessivamente, a partir das economias da madeira (o pau-brasil, que inclusive inspirou o nome de batismo do país), do ouro, açúcar, da borracha e do café (DAMATTA, 1997, p.134).

O sistema de valores que orienta na época não só os países Ibéricos, mas também os anglo-saxões, que praticaram o extrativismo predatório e a monocultura em grande escala, é marcado pelo antropocentrismo, e este por sua vez se assenta na concepção criacionista judaicocristã. A forte influência ibérica e do cristianismo no Brasil estabelece relações semelhantes entre o mundo natural e o mundo social. Ou melhor, ambas se organizam a partir da mesma hierarquia. Deus é o ente soberano, que tem o poder sobre o céu e a terra - nas Sagradas Escrituras o termo natureza não é utilizado -, depois vem o homem que, criado à sua imagem, tem o poder na terra de explorar e dominar a natureza para fazer respeitar a vontade divina e, por último, vêm as plantas e os animais, seres inferiores que devem se submeter às leis dos homens e de Deus.

Como observa Breton (1997), toda a doutrina da criação tem como elemento determinante mais o egoísmo do que a subjetividade. A criação só surge da submissão da natureza à vontade e às necessidades do homem. Segundo esse autor, ocorrem diversas implicações, entre as quais a principal a ser assinalada neste momento é que a natureza, como matéria, passa a ser reduzida a um material que "“não é nem em si, nem para si,' porque está exclusivamente ao serviço do homem; donde, um 'utilitarismo generalizado' que converte o ser num puro 'ser para', instrumental" (BRETON, 1997, p.151). Ao contrário do paganismo grego, que deu origem à ciência e à arte no Ocidente, que considera a natureza "em si" e "para si", "fora de toda a exploração, estranha ao capricho de um "verbo ditatorial, de um imperativo categórico, de um decreto mágico"”, o dogmatismo judaico-cristão, baseado no monoteísmo, na crença em um único Deus, fez da matéria o material que produz o útil e exalta o desejo. Todavia, isto não impediu ao longo do processo histórico, que tanto o cristianismo como o ocidente profano, a fé e a razão, a religião e a ciência, convergissem sob um mesmo paradigma cultural: Deus e o homem, a natureza e a História, são expressões de um mesmo princípio "colonizador" (BRETON, 1997, p.151).

Mas cabe salientar ainda que, não obstante ibéricos e anglo-saxões pertençam a uma mesma matriz do pensamento ocidental, há diferenças culturais entre os puritanos que colonizam a Nova Inglaterra ou os degredados britânicos que colonizam a Austrália e os espanhóis e portugueses que colonizam a Argentina ou o Brasil. Os primeiros também buscam o paraíso terrestre, mas ao chegar às novas terras sentem que acabam de deixá-lo. Suas impressões, do ponto de vista estético, são as piores; horrorizam-se com os indígenas e aborígenes, bem como a natureza lhes parece selvagem, agressiva, violenta e perigosa. Chegam às novas terras com o objetivo de fundar um novo mundo. Sabem que não há retorno e que esta natureza selvagem é a natureza na qual os homens, a partir do pecado original, estão condenados a viver e, portanto, precisam subjugá-la, domesticá-la, por meio de muito trabalho para que ela se torne o reino de Deus. Já os colonizadores ibéricos, como se observou, experimentam uma relação passiva com a natureza. No lugar do fundador, que estabelece suas ações e decisões pautadas por valores e normas ideologicamente construídos e contrários aos antípodas, o conquistador conta com as próprias forças naturais para fazer "descobertas" e, sobretudo, "descobertas por acaso", de modo que as instituições humanas não assumem responsabilidade no processo de constituição da sociedade. Sob esta lógica, tanto o conquistador se deixa seduzir pela exuberância da natureza quanto a natureza se oferece prestimosa ao conquistador, o qual se apropriará da riqueza natural e da força física humana durante séculos, não com o intuito de fincar raízes no novo mundo, mas de explorá-lo a partir do modelo social hierárquico e autoritário do seu país e, se possível, retornar a ele com sua identidade social melhorada pelos feitos produzidos além-mar.

Não obstante todos os esforços de coletar, registrar, catalogar, inventariar e conservar em frascos, gavetas e prateleiras, milhares de espécies presentes na Mata Atlântica, havia tantos outros milhares de habitantes naturais a serem descobertos. Os pesquisadores também não tinham acesso a muitas terras incógnitas, sendo que a maior parte das coletas desse período clássico da botânica e da zoologia era realizada "em praias ensolaradas, pastos, savanas e matas secundárias, não na floresta de sombras eternas, cuja multiplicidade de formas de vida abrigava-se, insuspeitada, no dossel a cinqüenta metros acima da cabeça dos naturalistas". 


\section{Naturalização da desigualdade}

No Brasil, esse sistema de valores religiosos e culturais orientou a exploração da natureza por meio de homens e mulheres (indígenas e escravos) que também eram considerados seres semelhantes à natureza, dotados de uma cultura inferior que precisavam ser subordinados e dominados pelos seus senhores, estabelecendo-se, dessa forma, como bem sintetiza Da Matta, uma relação de desigualdade e hierarquia, de tal maneira que, a uma representação da natureza como esfera passiva e metaforicamente concebida como serva-escrava do homem que dispõe dela como muito bem entende - corresponde uma estrutura social que se fundamenta, do mesmo modo, na passividade obrigatória do trabalho e na submissão total ao senhor (DAMATTA, 1997, p.140).

Nessa sociedade tradicional e hierárquica, as fronteiras entre o mundo natural e social são demarcadas ou reforçadas por capturas, castigos e crueldades impingidos aos animais domésticos, plantas e escravos. Sendo que os escravos - indígenas ou os negros trazidos da África - são o elo simbólico entre sociedade e natureza. Ao mesmo tempo, essa tênue fronteira entre natureza e sociedade é quase sempre ameaçada pela ambiguidade dessas relações, estabelecidas desde o primeiro contato do europeu com as terras descobertas ora como de embevecimento e gozo diante das paisagens exuberantes e da beleza, suavidade e inocência dos seus habitantes, ora como de usurpação e controle sobre a natureza selvagem e a bestialidade dos seus seres bárbaros que podem ameaçar a ordem civilizatória, ferir os mandamentos divinos e as leis estabelecidas pelos homens.

Inicia-se, assim, de acordo com DaMatta, um Estado em formação patriarcal, personalista e hierárquico que se valerá de uma mesma lógica para se relacionar com a natureza e com os próprios homens: a lógica da desigualdade. Mais uma vez, a carta de Pero Vaz de Caminha é exemplar a esse respeito. Embora a longa e eloquente descrição da "Terra descoberta" preencha a maior parte do conteúdo do documento oficial, ao final o relator pede a D. Manuel que interceda pela libertação do seu genro, Jorge Osório, que se encontrava preso na ilha de São Tomé, e que por duas vezes já havia obtido o perdão do rei por ter roubado e ferido um abade. Alguns historiadores especulam assim que as generosas palavras sobre as novas terras serviriam apenas para encobrir um pedido clientelista (DAMATTA, 1997, p.136).

E essa lógica, cabe ainda dizer, assenta-se sobre um princípio de naturalização das relações sociais. Em primeiro lugar, parece que a conquista das novas terras se faz ocasionalmente, por um acidente de percurso. Em segundo lugar, o contato entre grupos humanos estranhos se faz amistosamente, sem temores e aversões de ambas as partes. Em terceiro lugar, a terra se submete docilmente e os selvagens terão sua alma apaziguada logo que se apresentem a eles os preceitos cristãos. $\mathrm{Na}$ incapacidade daqueles se habituarem à vida disciplinada e laboriosa, os braços escravos provenientes da África serão densa e forçosamente utilizados para gerar a riqueza e o poder dos quais não irão desfrutar sequer em gerações futuras e, por fim, a miscigenação também se apresenta assim como resultado natural desse encontro casual. A história, dessa forma, emerge da natureza. Não é orientada por um sistema social criado por sujeitos que definem suas ações e são guiados por ideologias e valores, mas é fruto de um sistema natural em que os seres são sujeitados por forças naturais e misteriosas contra as quais não podem se rebelar.

Humilhações, resistências, dizimações por doenças e maus tratos, exterminação de línguas e culturas, fugas, lutas, estupros e demais formas de violência e violação dos princípios morais cristãos são também naturalmente varridos, durante muito tempo, da História do Brasil, o que evidencia que a rígida hierarquia social sob a qual se configurou a sociedade brasileira contribuiu para que até hoje, apesar de algumas mudanças significativas em relação à concepção de natureza, que serão analisadas mais adiante, prevaleça uma sensação de que vivemos eternamente, como reforça a letra da canção de Jorge Benjor, "num país tropical, abençoado por Deus e bonito por natureza", e que a passividade diante dos acontecimentos é apenas um jeito brasileiro de ser.

\section{A redescoberta europeia da natureza brasileira}

A transferência da Corte portuguesa para o Brasil, em 1808, após a invasão de Portugal pelas tropas francesas do imperador Napoleão Bonaparte, contribuiu para estimular algumas mudanças na vida brasileira. Além de o regente do reino, D. João, criar algumas instituições significativas 
como o Banco do Brasil, a Academia Militar e da Marinha, a Imprensa Régia, a Biblioteca Real e o Jardim Botânico, toma a decisão de abrir os portos às nações amigas, assim como concede permissão para a abertura de fábricas e manufaturas brasileiras.

Com a abertura dos portos não só são incrementadas as atividades econômicas e comerciais de importação e exportação, que passam a ser desviadas de Portugal, então ocupado pelos franceses, para o Brasil, como também aumenta a presença de estrangeiros no país motivados por outras finalidades como as expedições feitas por artistas e naturalistas, encabeçadas por academias e sociedades científicas e financiadas por monarcas que, em nome da arte e da ciência, percorrem vastas regiões do país buscando conhecer e retratar em detalhes a conformação e a as riquezas da natureza brasileira. Esses cronistas e naturalistas, vindos de toda parte da Europa, serão responsáveis pelos primeiros registros documentais que nortearão a produção intelectual sobre o Brasil no Velho Mundo e influenciarão posteriormente os brasileiros que se dedicarão a pensar e escrever a história do Brasil, assim como aqueles que assumirão o papel político de esquadrinhar e definir essa natureza como patrimônio da nação emergente.

Imbuídos do espírito ilustrado e dos valores iluministas que defendiam o primado da razão, do progresso, da tolerância e do humanismo, os homens que faziam parte das missões científicas de algum modo se sentiam como os novos descobridores do Brasil e, às vezes, expressavam literalmente esse sentimento em seus relatos de viagem, como é o caso do engenheiro Bigg-Wither, quando descreve suas impressões ao chegar próximo da cidade do Rio de Janeiro, a bordo do navio Lusitânia, em 1872:

A superfície desta vasta baía, que cobre uma área de mais de cem mil milhas quadradas, era tranquila e cristalina, não perturbada por ondas ou ondulações. As montanhas e o cenário de em torno se refletiam nela como se o fosse numa superfície de aço polido. Aqui e acolá, ilhas verdes espalhadas projetavam longas e profundas sombras na água. Não havia o mais leve sopro de brisa. Nenhum mastro ou vela eram vistos. Tudo parecia tranquilo, calmo e deserto, como na época em que a primeira embarcação bem-aventurada, três séculos antes ou mais, varou a solidão da natureza selvagem deste lugar [grifo meu] (BIGG-WITHER, 1974, p.37).
Apesar dos séculos que separam esses estudiosos e profissionais europeus dos antigos colonizadores e, em certa medida, das circunstâncias que os trazem ao Brasil, o sentimento ambíguo de medo e deslumbramento diante da natureza parece se repetir, assim como se sentem impelidos pelo mesmo espírito de aventura dos primeiros navegadores.

\section{O olhar cientifico sobre a natureza}

Muito antes de Bigg-Wither, na primeira metade do século XIX, outros jovens estudiosos naturalistas imbuídos do espírito científico, chegaram ao Brasil dispostos a palmilhar todo o território para conhecer o clima, a geologia, as espécies vegetais e animais, coletar seus exemplares, compará-los, classificá-los, catalogá-los, identificar suas utilidades para o desenvolvimento comercial, industrial e científico das nações europeias Os bávaros Johann Baptist von Spix (zoólogo) e Karl Friedrich Phillip von Martius (botânico) vieram para o Brasil em 1817, graças a um acordo entre o rei da Baviera, Maximilian Joseph I e o imperador da Áustria, Francisco I, que permitiu aos dois naturalistas integrar a missão científica austríaca que acompanhou a arquiduquesa Leopoldina, filha de Francisco I, que vinha para o Brasil em razão do casamento com o príncipe D. Pedro I. Dessa expedição fizeram parte também Thomas Ender, Johann Buchberger, Franz Joseph Frühbeck e Frick (pintores), Ferdinand Dominik Sochor (caçador e preparador), Heirinch Wilhelm Schott (jardineiro), Rochus Achüch, Johann Natterer, Giuseppe Raddi, Johann Emanuel Pohl e Johann Christian Mikan (naturalistas).

Entre 1822 e 1829, outros viajantes que se tornaram ilustres foram Georg Heirich von Langsdorff, João Maurício Rugendas e Adriano Taunay (artistas) que, junto a outros como Hércules Florence (também artista), Eduardo Menétries e Christian Hasse (zoólogos), Alexandre Rubsow (astrônomo) e Luiz Riedel (botânico), vieram patrocinados pelo império Russo (COSTA; DINER, 1995). Além de Alexander von Humboldt, Auguste Saint-Hilaire, Friedrich Salathé, Alexandre Rodrigues Ferreira, os quais se tornaram muito conhecidos, dentro e fora do Brasil, pela exposição e publicação de pinturas, gravuras e descrições minuciosas acerca da natureza e da população existente no Brasil, entre os séculos XVIII e XIX. 
Traço comum a tais observadores, especialmente dentre os naturalistas que vêm respaldados por comissões de estudos, é uma formação científica ainda pouca especializada e compartimentada, o que torna seus relatos - resultados de pesquisa teórica e observação empírica - extremamente minuciosos e abrangentes, percorrendo vários temas de modo interligado. Como observa Lisboa (1995), em seu estudo sobre a expedição científica pelo Brasil feita pelos bávaros Spix e Martius, embora a especialidade de cada um fosse respectivamente zoologia e botânica, e a expedição tivesse como objetivo explícito o estudo da zoologia e da flora brasileira em toda a sua extensão, outros temas relacionados às ciências humanas seriam notoriamente observados e registrados como a política, a economia, as condições sociais e culturais, as diversões, os transportes, as técnicas, a música, a etnologia, a administração pública, a religião, além da geologia e da climatologia.

Esses viajantes seguiram por São Paulo, Rio de Janeiro, Minas Gerais, Bahia, Pernambuco, Maranhão, Pará e Amazonas. Por terra ou por mar, embrenhando-se pela mata ou caminhando pelas vilas e cidades, interpretando as variáveis regionais sob o ponto de vista da sua população e do seu ambiente físico; nota-se, todavia, nesses relatos que a natureza era a grande protagonista, para a qual se dirigiam as principais observações de Spix e Martius (1976). A percepção da natureza por esses naturalistas está impregnada por sua formação cultural e pela influência acadêmica da História Natural.

Conforme analisa Foucault (1985, p.144), embora tivesse se desenvolvido em um clima empírico, a História Natural não se contentava só em ver, mas se fundamentava num modo de representação que "[...] é a possibilidade de ver o que se poderá dizer, mas que não se poderia dizer depois, nem ver, a distância, se as coisas e as palavras, distintas umas das outras, não se comunicassem desde o início, numa representação". A influência da ordem descritiva de Lineu estará presente na forma como esses historiadores da natureza se aproximam da natureza. Vegetal ou animal, o elemento da natureza é um objeto a ser definido sistematicamente segundo os passos indicados por Lineu: nome, teoria, gênero, espécie, atributos, uso e, por fim, litteraria. Ou seja, por último, toda a linguagem discursiva que relatasse as tradições, as crenças, as figuras poéticas, mas fundamental antes é o naturalista olhar minuciosamente as coisas e "transcrever, em seguida, o que ele recolhe em palavras lisas, neutralizadas e fiéis" (Foucault, 1985, p.145). Depois de essas plantas e esses animais serem "purificados" pela taxonomia, comporão herbários, coleções, jardins, onde os seres naturais estarão visíveis, ordenados segundo traços comuns, devidamente analisados e nomeados.

A representação científica da natureza adotada pelos naturalistas do século XIX, portanto, deve reduzir as distâncias, "para conduzir a linguagem o mais próximo possível do olhar, e as coisas olhadas, o mais próximo possível das palavras" (FOUCAULT, 1985, p.146), a fim de que as coisas descritas sejam reconhecíveis por todos, segundo regras positivas e objetivas.

\section{A inspiração poética do quadro natural}

Concomitante a essa apreensão "neutra", "distanciada" da natureza, manifesta-se nos relatos de Spix e Martius, como também no relato dos demais viajantes da época, outra concepção de natureza marcada pela expressão de sentimentos provocados pelo contato com o ambiente natural. Os relatos desses naturalistas, assim como o do já citado Bigg-Wither, revestem-se de um forte apelo literário muito em voga no cenário intelectual europeu da época: o romantismo ${ }^{3}$. E essa linguagem poética contrasta notoriamente com o rigor da linguagem acadêmica. Spix e Martius (1976, p.185-6), ao relatarem a viagem noturna entre as cidades do Rio de Janeiro e de São Paulo, "sob o luar", parecem se embevecer diante da Serra da Mantiqueira: “[...] os seus contornos azulados formavam um mágico fundo de cenário, no qual se alternavam matas e lugares abertos. As altas árvores do mato, entre as quais transitávamos, estavam envoltas em sombras negras, e frequentes vezes ali ressoavam estranhos sons de vozes noturnas, nunca antes percebidas; tudo se combinava para transportar-nos a um raro, tanto quanto singular, estado de alma".

A linguagem poética excita o imaginário do leitor e as palavras eivadas de subjetividade como "mágico fundo de

\footnotetext{
${ }^{3} \mathrm{O}$ romantismo, como movimento artístico-literário, irrompeu na Europa no século XVIII, lentamente preparado pelos pré-românticos - escritores e poetas que embora se revelem clássicos como os seus contemporâneos, experimentaram inovações nas suas tendências morais e modelos estéticos. O Romantismo se estendeu praticamente por todos os países europeus e depois se expandiu para outros continentes, teve sua fase áurea na primeira metade do século XIX, ao fim da qual perdeu terreno para o Realismo.
} 
cenário", "contornos azulados, "sombras negras", estranhos sons de vozes noturnas" o transportam para uma dimensão da realidade bastante diferente daquela que pouco antes havia sido descrita com imparcialidade e precisão acerca dos recortes geográficos, das inúmeras variedades de árvores e das suas utilidades, assim como os supostamente cognoscíveis e complexos nomes científicos dos animais.

O engenheiro Bigg-Whiter (1974, p.94), do alto de um penhasco, e sem receio de que o chamassem de "exagerado" também fazia igualmente uma observação sentimental do Vale do Tibagi:

[...] para o lado do sul e do sudoeste, estendia-se vasto mar de relva dourada que se perdia de vista, ondulando em vagas gigantescas até o profundo Vale do Iguaçu, bem distante e muito abaixo; depois elevando-se novamente do outro lado, continuava o seu movimento ondulatório, diminuindo gradativamente as vagas, até o céu e a terra se confundirem e se perderem na distância, no que parecia ser o infinito.

Observa-se, assim, que a forma como os viajantes europeus referem-se à natureza brasileira "lembra o que Humboldt - "estrela guia dos viajantes do período e que inúmeras vezes é mencionado na Viagem pelo Brasil, de Spix e Martius - propusera numa carta dirigida a Goethe: 'a natureza deve ser sentida; quem somente vê e abstrai, numa vida no turbilhão do pulsar dos trópicos ardentes, pode dissecar plantas e animais, acreditando estar descrevendo a natureza, permanecendo, no entanto, eternamente alienado dela" (hUMBOLDT apud LISBOA, 1995, p.79).

Ou seja, para conhecer a natureza não bastava percebê-la "para si", mas igualmente "em si", como se o "estado da alma" inspirado por ela revelasse não só a experiência do observador diante do seu objeto, mas o objeto em si se revelaria na sua essência. Essa descrição da "totalidade" da natureza, possibilitada pela ligação da ciência com a poesia, conforme Lisboa (1995, p.80), demonstra a influência de Goethe sobre o pensamento de Spix e Martius, o qual "considerava o mundo natural como um 'grande animal vivo, um organismo que jamais poderia ser traduzido matematicamente', opondo-se desta maneira a qualquer "tendência mecanicista".

Daí talvez o grande interesse que essas obras despertavam no púbico europeu visto que, além de saciar a curiosidade científica acerca da estrutura dos seres da natureza e de suas variáveis, dava-se um tratamento estético às descrições, inclusive complementada por iconografia feita muitas vezes pelos próprios naturalistas, a fim de apresentar um fiel e completo quadro da natureza, traduzindo dessa forma a sua totalidade e o sentimento de encantamento diante da harmonia das cores, dos sons e das formas que faz da natureza mais do que um objeto da ciência uma verdadeira obra de arte.

\section{A natureza como inimiga}

Mas não era só de esclarecimentos científicos e encantamento derradeiro diante do esplendor da natureza que se regozijava o europeu que lia os relatos das aventuras dos naturalistas nos trópicos. Constam também dessas narrativas as desventuras experimentadas pelos estudiosos e seus acompanhantes europeus e brasileiros que tinham de enfrentar "inúmeros inimigos dos homens, que são anualmente gerados pelo calor e umidade destas grandes estufas - as florestas tropicais" (BIGG-WHITER, 1974, p. 212). Após uma chuva forte que desmontou as barracas e encharcou as camas e cobertas de todo o grupo da expedição, Bigg-Whiter (1974, p.101) constata: "certamente, os grandes campos do oeste, apesar de seus horizontes sem fim e de seus soberbos espetáculos, nem sempre são cor-de-rosa".

Não era incomum durante essas expedições a ocorrência de mortes e doenças de alguns integrantes dos grupos, resultantes da inadaptação às condições climáticas e ao ataque dos insetos que causavam feridas, inflamações e infecções graves. O próprio modo de vida que levavam os viajantes, com longas e extenuantes marchas a pé ou sobre o couro de mulas, atravessando diversas regiões e mudanças climáticas, enfrentando o verão dos trópicos - a estação do ano considerada a mais penosa para o europeu - contribuía para a sobrecarga de trabalho de uma parcela do grupo, atraso nas viagens e desgaste físico e psicológico da maioria dos participantes.

Tais condições adversas propiciavam uma percepção negativa em relação aos ataques da natureza selvagem. Em relato sobre a primeira noite no campo, Bigg-Whiter relembra as leituras de Mayne Reid ${ }^{4}$ e comenta sobre as

\footnotetext{
${ }^{4}$ Escritor irlandês que ficou famoso em meados do século XIX por suas novelas de aventuras ambientadas no México, Himalaia, África e Jamaica.
} 
armas mantidas juntas, em volta do poste central da barraca “[...] com que poderíamos repelir ataques de homens e feras, pois ainda não sabíamos se seríamos ou não atacados por algum feroz touro selvagem ou por índios de cara pintada. É muito difícil a gente libertar-se de ideias sensacionais incrustadas em nossas cabeças de moços" (BIGG-WHITER, 1974, p.100).

Imaginação e realidade se embaralhavam na cabeça dos viajantes apreensivos diante de tantas novidades ofertadas pela natureza dos trópicos e do medo do desconhecido e imprevisível. Mas, curiosamente, os ataques de animais ferozes que mais assustam e desestabilizam o humor dos viajantes não são os das onças ou dos tigres - que ademais são raramente confrontados ou são confundidos com outros animais de médio e grande porte como o porco do mato e a anta -, mas os ataques dos minúsculos e insuportáveis insetos. Tanto os relatos românticos de Spix e Martius quanto os de Bigg-Wither não resistem à necessidade de desabafar e expressar os irritantes ataques de moscas, mosquitos, vespas, marimbondos, abelhas grandes e botucas, que além de numerosas eram "incômodos" e "inoportunos". Mas, sem dúvida, nota-se que há consenso quanto ao mais desagradável dos inimigos na floresta: os "repugnantes" carrapatos (SPIX; MARTIUS apud LISBOA, 1995, p. 83; BIGG-WHITER, 1974, p. 194).

Tais sentimentos desagradáveis em relação à natureza eram ocasionados igualmente pelas dificuldades de transporte. Como para adentrar algumas regiões era necessário abrir picadas e carregar vários objetos como espingardas, rifles, pistolas, redes, arpões, sacolas de cartuchos, facões, pratos, copos e alimentos, decidiamse não carregar barracas e os acampamentos eram feitos então ao relento "sem cobertas, sem fogueira ou comida". $\mathrm{O}$ desconforto aumentava nas campinas quando se aproximavam urubus, abutres e gaviões e o "[...] barulho, feito principalmente pelos papagaios e pica-paus, com o grito ocasional do gavião cinzento, era, naquela hora, ensurdecedor" (BIGG-WHITER, 1974, p.111).

Talvez um dos inimigos mais ameaçadores e que causavam muito pavor entre os viajantes, tanto quanto os carrapatos, eram as pulgas. Elas invadiam os acampamentos, eram as responsáveis pelas muitas noites de insônias dos viajantes e abatiam severamente o ânimo dos pesquisadores e de seus animais acompanhantes. Alguns incidentes como os sustos causados por cobras ou mosquitos invasores durante as noites de verão podiam ser relevados, embora fossem desagradáveis,
[...] mas, infelizmente, havia por baixo de tudo uma tendência oculta de grande miséria que, para ser devidamente apreciada, precisa ser sentida. Miríades de pulgas ferviam no acampamento. Os cães (...), tornaramse, como era de esperar, as suas principais vítimas. Dia e noite eles se mostravam inquietos no acampamento, procurando em vão fugir aos tormentos, escondidos nos cantos, ou rolando nas cinzas dos braseiros, latindo, rosnando e mordendo furiosa e dolorosamente as próprias costas (BIGG-WHITER, 1974, p.249).

E os homens também sofriam, embora Big-Whiter indicasse que, no seu grupo, ele é o que mais sofria com o ataque das pulgas: "[...] eu não suportava mais. Meu cérebro começou a ficar tão enfraquecido, por prolongada falta de sono, que não pude mais trabalhar" (1974, p.250). Tais condições e a constante vigília com medo de ser atacado pelas pulgas impertinentes ou devorado por onças, que deixavam seu rastro próximo ao acampamento, faziam Bigg-Whiter tirar conclusões que em nada lembram a visão idílica e harmoniosa do homem com a natureza: "vemos, assim, que do maior mamífero até o mais bonito inseto, a guerra - a guerra implacável e incessante - é condição normal da natureza nestas grandes florestas primevas. Que os moralistas tirem as suas lições disso" (1974, p.251).

Spix e Martius, cinquenta e poucos anos antes, já haviam se referido aos infortúnios causados aos naturalistas e aos lavradores recém-chegados da Europa pela "inoportuna bicharia" (mosquitos, bichos-de-pé, cupim, barata, pulgas e carrapatos), sem contar as "onças ferozes, as cobras venenosas, lagartos, escorpiões, lacraias e aranhas". Mas eles vislumbravam a solução para todos os incômodos e obstáculos que podiam ser impostos pela natureza. Mediante o progresso do povoamento, da instrução no país e o emprego de "recursos idôneos" os obstáculos podiam ser minorados ou evitados e, aos poucos, iriam desaparecer, "quando os habitantes deitarem abaixo as matas, dessecarem pantanais, rasgarem estradas por toda parte, fundarem aldeias e cidades, triunfarem da exuberante vegetação e dos bichos daninhos, então todos os elementos virão ao encontro da atividade humana e recompensarão plenamente" (SPIX; MARTIUS, 1976, p.90).

Sob esse ponto de vista, a guerra contra os inimigos naturais já havia sido ganha pela ciência e pela civilização europeia que, mais cedo ou mais tarde, domesticariam os homens e a natureza do Brasil, bem como fariam 
desaparecer todos os elementos que se opusessem à marcha do processo civilizatório, tal como o triunfo da dominação colonial portuguesa já fizera desaparecer centenas de nações indígenas e milhares de espécies vegetais e animais nos séculos anteriores.

Embora os naturalistas que vinham para o Brasil tivessem influência do pensamento ilustrado ou enciclopedista não seguiam a risca muito dos seus princípios como, por exemplo, o ataque à monarquia e à Igreja Católica. Ao contrário, suas atividades e funções dependiam do patrocínio de monarcas e mantinham sua fé inabalável em Deus concomitante à crença na ciência e na técnica. Tal como os enciclopedistas, eles acreditavam que todos os seres humanos podiam transitar da barbárie à civilização, desde os "selvagens" da América aos europeus. Ao mesmo tempo, os preceitos liberais do final do século XVIII pareciam também influenciar o modo de pensar desses viajantes.

Teoricamente, para os liberais, a natureza humana era considerada igual em toda parte. Embora alguns povos fossem considerados mais primitivos do que outros, todos tinham seus talentos e sua capacidade de progredir, independente do sexo ou da raça. O liberalismo econômico pregava uma comunidade mundial interdependente, baseada na divisão internacional do trabalho. O liberalismo político combatia o imperialismo, a imposição da vontade de um povo sobre o outro. Na esfera do saber e da moral, havia uma preocupação com os direitos das mulheres (Stuart Mill apoiava as feministas na Inglaterra), dos negros (campanha contra a escravidão nos EUA e no Brasil) e dos povos subjugados, colocando-se contra o colonialismo. Na prática, porém, o universalismo pregado pelos liberais tornou-se extremamente problemático: propagaram-se teorias baseadas numa suposta hierarquia, separando os povos europeus - no topo da escala - dos povos não europeus e legitimou-se a superioridade da raça branca ${ }^{5}$.

Spix, Martius, Bigg-Whiter e muitos outros viajantes não escaparam de todas essas influências teóricas e das suas confusas expressões concretas. Para eles, não restavam dúvidas que índios eram selvagens, degenerados e os piores exemplares da espécie humana, quando era possível acreditar que eles fossem mesmo humanos ${ }^{6}$. Spix e Martius dedicam alguma reflexão, no primeiro volume de Viagem pelo Brasil, ao tema das diferenças entre europeus, negros e índios e à superioridade dos primeiros em relação ao "desenvolvimento superior dos órgãos e forças intelectuais". Ao europeu pertence a verdadeira humanidade, inseparável da ideia de liberdade. A liberdade fundamentada na viva consciência moral, e desenvolvida pela delícia da religião e da autêntica ciência, imprimiu ao europeu o cunho da dignidade e grandeza, que até aqui o têm guiado quase involuntariamente [mais uma vez por obra do acaso?] por todas as partes do mundo, sempre vitorioso (SPIX; MARTIUS, 1976, p.144).

Bigg-Whiter não disfarçava sua repulsa pelos indígenas, mas mesmo diante de alguns botocudos capturados por sua expedição, considerados "a tribo mais selvagem e degenerada de todos os aborígenes sul-americanos", surpreende-se com algumas semelhanças que aqueles teriam com o europeu como, por exemplo, em relação às ideias de enfeite pessoal: "o europeu moderno, bastante culto, tem certamente muito em comum, em matéria de senso artístico, com o seu irmão botocudo [grifo meu], sendo um dos pontos de semelhança mais notáveis a necessidade aparente de ambos de fazer um orifício nalgum lugar do corpo onde possam pendurar alguma coisa" (BIGG-WHITER, 1974, p.328).

Embora Spix e Martius em Viagem pelo Brasil expusessem seus preconceitos abertamente em relação aos índios, em outro trabalho realizado mais tarde por Martius, Como se deve escrever a história do Brasil, premiado e publicado pelo Instituto Histórico e Geográfico Brasileiro, em 1847, a ideia da miscigenação de raças como triunfo da civilização nos trópicos é retomada, e desta vez, a figura do índio aparece de forma positiva no processo de caldeamento (LISBOA, 1995, p.88). Restava, portanto, para fazer do Brasil uma nação civilizada, apostar na miscigenação racial em que o europeu (raça caucásica), com sua força superior sobrepor-se-ia ao negro (raça etiópica) e ao índio (raça americana) formando um povo inteligente, vivaz e forte"

\footnotetext{
${ }^{5}$ Ver mais detalhes sobre o pensamento iluminista na tradição histórica do enciclopedismo, liberalismo e socialismo em ROUANET, Sérgio Paulo. Mal estar na modernidade: ensaios. São Paulo: Companhia da Letras, 1993.

${ }^{6}$ Os pensadores europeus desde o início do período moderno já acreditavam que a essência da humanidade, que a diferenciava dos animais, mas também de outros grupos humanos, consistia em alguma qualidade específica (tecnologia, linguagem inteligível, religião cristã) que, se não fosse encontrada em outros homens, poderse-ia considerá-los "sub-humanos" ou "semi-animais". Ver mais detalhes em THOMAS, Keith. O homem e o mundo natural: mudanças de atitude em relação às plantas e aos animais (1500-1800), p.49-60.
} 
para a qual já contribuíam as "esplêndidas disposições naturais" (SPIX; MARTIUS apud LISBOA, 1995, p.87).

O estudo de Martius, sugerindo a composição das três raças como fio condutor da história do Brasil, teria posteriormente significativa influência sobre o pensamento de vários intelectuais brasileiros e sobre a concepção de uma identidade genuinamente brasileira, que daria sentido e significado aos esforços de se construir a nação brasileira, dentre outros modos, a partir da escrita da história e da geografia de como se forma a população e o território brasileiro.

\section{Saberes sobre o mundo natural: selvagens $x$ civilizados}

Assim como os viajantes de várias profissões, e especialmente os naturalistas, procuravam fazer uma descrição isenta, desapaixonada e objetiva das plantas e dos animais, a mesma tentativa se sucedia com relação aos homens, mulheres e crianças tão diferentes em suas feições físicas e comportamento moral dos seus referenciais europeus. No entanto, como já foi observado, quase sempre se tornava impossível não expor, por meio da linguagem, os seus juízos morais e estéticos, assim como o sentimento de superioridade em relação aos silvícolas, aos caboclos, aos brasileiros de modo geral. Ao mesmo tempo em que pendiam para a aceitação da diversidade do mundo e dos seres vivos, imbuídos do romântico point de vue spetaculaire, aqui e acolá, são usados termos pouco elegantes ou até mesmo insultantes para se referir aos indígenas ou aos brasileiros.

A percepção pejorativa do "outro" ocorre frequentemente em concomitância ao reconhecimento de determinadas (boas) qualidades que não podem deixar de ser citadas porque são percebidas a todo o momento, durante a viagem. Ou melhor, as expedições praticamente não podem obter sucesso sem que, em meio aos suecos, franceses, bávaros, ingleses e russos, não estejam presentes alguns índios, negros ou caboclos para orientar o caminho, abrir uma picada, preparar a comida, dar informações sobre plantas e animais. Mas, é claro, a taxonomia é a regra, e a nomenclatura científica a lei, sendo que os nomes vulgares/ populares são apenas um estágio inferior do conhecimento e uma maneira de estabelecer a comunicação com esses seres que, apesar de "incultos" e "inferiores", demonstram às vezes, talvez pela sua proximidade com natureza - metade bicho, metade homem -, algumas habilidades admiráveis.

Spix e Martius, por exemplo, durante um trecho da sua viagem por São Paulo tinham a companhia de um lavrador local. Depararam-se com várias qualidades de madeira, dentre elas, as vulgarmente denominadas sebastião-de-arruda, coração-de-negro, jacarandá, cedro, peroba, jequetibá. Decidiram colecionar 120 qualidades de madeira em virtude de parecerem próprias para a construção de prédios, navios e móveis. Admiraram-se diante da facilidade do guia que não só sabia o nome vulgar de cada árvore, mas igualmente a sua finalidade, a época da florescência e o gênero de frutos. Constatam que o fato de os "homens simples" estarem em contato frequente com a natureza lhes dá uma percepção exata das características físicas das espécies e, neste ponto, eles superam geralmente o europeu, muito ilustrado, mas pouco observador da natureza. [...] Igualmente o sertanejo é notável pelo conhecimento das plantas medicinais de sua terra; sobretudo as mulheres, entre os habitantes desta província, têm fama de grande proficiência na prática da medicina (SPIX; MARTIUS, 1976, p.141).

Ao mesmo tempo em que reconhecem o saber do sertanejo, estabelecendo inclusive comparações favoráveis ao saber popular, a seguir apressam-se em inferir que esses "conhecimentos práticos" não foram herdados dos indígenas pela atual geração de brasileiros. Nas palavras dos naturalistas bávaros,

[...] o longo convívio com os índios convenceu-nos de que a indolência desses infelizes os impossibilita de investigar as propriedades curativas da natureza. Superstição, indiferença pela vida e insensibilidade pelos sofrimentos do próximo não deixam que os índios se utilizem dos dons com que por toda parte os cerca a generosa natureza (SPIX; MARTIUs, 1976, p.142).

Termos semelhantes como "infelizes", "horríveis", "selvagens", "idiotas" eram usados por Bigg-Whiter que dedicou várias páginas a descrever minuciosamente as características físicas, rituais e hábitos de caiuás, botocudos e coroados, alguns dos quais foram capturados pela sua expedição que tentava, muitas vezes em vão, “civilizá-los". Ao contrário de Spix e Martius, no entanto, Bigg-Whiter identificava alguns saberes desses índios em relação ao transporte fluvial, em especial a agilidade 
dos caiuás como remadores, à construção de palhoças usando palmeiras, varas de bambu e cipós, as quais eram bem mais apropriadas para os acampamentos do que as suas barracas feitas de pesadas lonas, e admitia ainda a sabedoria indígena, repassada aos brasileiros, quanto ao uso de plantas medicinais. Aqui e acolá, surgem indícios do seu relativo apreço pelo indígena ou pelo brasileiro quando, por exemplo, refere-se à habilidade dos "machadeiros" - brasileiros que acompanham a expedição e que fazem as picadas com foices brasileiras, visto que as foices inglesas trazidas se mostram impróprias -, que demonstram grande habilidade na derrubada das árvores, hora "em que começa a exibição da força, resistência e habilidade, raramente testemunhada no brasileiro, exceto nestas ocasiões" (BIGGWHITER, 1974, p.186).

\section{Da exploração (econômica e científica) à proteção (patrimonial) da natureza}

Alguns dos viajantes europeus e suas impressões sobre a natureza e os habitantes do Brasil, aqui citados, tiveram difusa e significativa influência na formação da intelectualidade brasileira e numa certa maneira de perceber e agir sobre a natureza. A detalhada e abrangente abordagem dos aspectos físicos, geográficos, econômicos, sociais e culturais do território e da população brasileira serviram de referência e análise para várias gerações de pensadores brasileiros que, em graus e formas variados, continuam se perguntando: o que une este país? O que caracteriza a natureza brasileira ou o chamado patrimônio natural brasileiro? Como conciliar a visão produtivista e a ação devastadora sobre a natureza predominante no Brasil tradicional e a visão protetora da natureza e suas tentativas de conter a devastação e construir o Brasil moderno?

A inquietude com a destruição da natureza no Brasil, ao contrário do que às vezes se diz, não é recente. Vários estudos contemporâneos têm revelado que esse tema permeia o pensamento social e político brasileiro desde os tempos coloniais ${ }^{7}$. A chamada consciência ecológica e o advento de numerosos movimentos de cunho ambientalista no panorama mundial foram impulsionados a partir dos anos 1960, ganharam destaque nas décadas seguintes com a globalização e a chamada crise da modernidade, mas a percepção e o mal-estar de intelectuais, cientistas e políticos ao longo da história do Brasil, ligados direta ou indiretamente aos rumos do desenvolvimento do país, já anunciavam desde muito antes o que se tornaria um dos principais problemas a serem resolvidos nos séculos seguintes: a proteção da natureza.

Entre o fim do período colonial e o final do Império, ou seja, no decorrer de um século, conforme estudo realizado por José Augusto Pádua (2002), foram produzidos cerca de 150 textos por 38 autores que refletiram sobre o processo de devastação do território brasileiro, as consequências econômicas e sociais de práticas irracionais e a indicação de soluções que poderiam conter ou atenuar a destruição dos estoques naturais. Tais autores quase sempre estavam diretamente ligados às ciências naturais e a instituições de pesquisa europeias, ou então exerciam cargos políticos. No primeiro caso, por exemplo, Pádua cita Alexandre Rodrigues Ferreira (1756-1815). Baiano de nascimento e considerado um dos principais naturalistas luso-brasileiros da época, Ferreira fez uma "viagem filosófica" pelo interior da Amazônia até o Mato Grosso, descrevendo em palavras e desenhos a agricultura, a fauna e a flora, os habitantes locais. Tal como os cronistas e viajantes do século XVI e XVII, seus estudos resultaram em coleta e envio de amostras de espécies vegetais e animais que iriam enriquecer o acervo de história natural do Real Museu de Lisboa.

$\mathrm{Na}$ outra ponta, Pádua destaca José Bonifácio de Andrada e Silva (1763-1838), que, reconhecido historicamente como o "patriarca da Independência", foi também, segundo o historiador, "o primeiro pensador brasileiro a estabelecer um nexo causal entre o escravismo e a destruição ambiental" (PÁduA, 2000, p.133). Para José Bonifácio, os braços escravos, que desmatavam e queimavam as terras, deveriam ser substituídos pelos braços

\footnotetext{
${ }^{7}$ Ver DEAN, Warren. A ferro e fogo: a história da devastação da mata atlântica brasileira. São Paulo: Companhia das Letras, 1997; PÁDUA, José Augusto. Natureza e projeto nacional: as origens da ecologia política no Brasil. In: PÁDUA, José Augusto (Org.). Ecologia e política no Brasil. Rio de Janeiro: Espaço e Tempo/Iuperj, 1987; _. . Um sopro da destruição: pensamento político e crítica ambiental no Brasil escravagista (1786-1888). Rio de Janeiro: Jorge Zahar, 2002; PRESTES, Maria Alice. A investigação da natureza no Brasil Colônia. São Paulo: Annablume, 2000; ABREU, Maurício de Almeida (Org.). Natureza e sociedade no Rio de Janeiro. Rio de Janeiro: Secretaria Municipal de Cultura/DGDI, 1992; HEYNEMANN, Cláudia. Floresta da Tijuca: natureza e civilização - século XIX. Rio de Janeiro: Secretaria Municipal de Cultura/DGDI, 1995; DRUMMOND, José Augusto. Devastação e preservação ambiental no Rio de Janeiro. Niterói: Editora da UFF, 1997. Outro trabalho interessante, porém mais específico, é o de SEGAWA, Hugo. Ao amor do público: jardins no Brasil. São Paulo: Studio Nobel/Fapesp, 1996.
} 
livres dos pequenos proprietários, que teriam interesse e necessidade de aproveitar as terras. Embora passando boa parte da sua vida na Europa e dedicando-se longamente às atividades políticas, Bonifácio publicou textos como Memória sobre a pesca da baleia e a extração do seu azeite (1790), Memória sobre a utilidade do plantio de novos bosques em Portugal (1815) e redigiu diversas notas manuscritas, enviadas aos seus pares da elite portuguesa, discorrendo sobre as suas ideias e projetos para o Brasil, nessas notas tratando do problema dos recursos naturais. Por exemplo, no texto sobre a pesca da baleia (Pádua adverte) se encontram os três elementos teóricos que estarão presentes e constituirão o cerne de toda a obra de Bonifácio: “[...] a visão de mundo fundada na economia da natureza, a defesa do progresso econômico pela aplicação do conhecimento científico às técnicas produtivas e a crítica à exploração destrutiva dos recursos naturais" (PÁDUA, 2002, p.123).

Esses elementos teóricos não estão presentes só na obra de José Bonifácio de Andrada e Silva como também permeiam a de Alexandre Rodrigues Ferreira e alguns outros pioneiros da hoje chamada ecologia política brasileira que foram recuperados por Pádua. Um traço comum a todos eles é terem obtido a sua formação intelectual na Universidade de Coimbra, depois da reforma universitária pombalina de 1772, e na Academia Real de Ciências de Lisboa, fundada em 1799. Todos eles foram influenciados, especialmente Bonifácio, por uma importante figura da reforma universitária portuguesa: o naturalista italiano Domenico Vandelli (1735-1816). Vandelli foi um entusiasta e difusor do uso da natureza para fins econômicos, nos moldes da corrente científica liderada por Lineu, que pregava a então chamada economia da natureza e que daria origem, em meados do século seguinte, ao termo ecologia.

O que o amplamente documentado estudo de Pádua revela sobre esses atores sociais que ainda viviam no Brasil unido politicamente a Portugal é uma coerência intelectual com o universo político e social do qual faziam parte. $\mathrm{Ou}$ seja, esses homens públicos, imbuídos de poder social, mas sem influência bastante para mudar o sistema social e econômico em vigor, eram ilustrados e reformadores em suas ideias Naquele contexto, a natureza não detinha em si nenhum valor, não era algo a ser preservado essencialmente por seu valor estético ou ético. Imbuídos de uma visão antropocêntrica e cientificista, a natureza era percebida por eles em sua objetividade, para fins pragmáticos. Dela se deviam extrair todas as informações para o conhecimento científico aplicado, a compreensão dos seus mecanismos para maior racionalidade e aproveitamento econômico, as vantagens políticas para uma futura unidade nacional e, consequentemente, o uso adequado dos seus recursos para o país ingressar na modernidade sem destruir ignobilmente suas fontes naturais.

O estudo de Franco, outro historiador contemporâneo, identifica na transição para o sistema de governo republicano, especialmente no período entre 1890 1914, um grupo de cientistas e políticos assemelhados que colaboraram para a formação de um pensamento mais sistemático sobre a proteção da natureza no Brasil (FRANCO, 2002; FRANCO; DRUMMOND, 2004). Ligados a instituições de caráter científico-cultural, como o Museu Nacional e o Jardim Botânico (no Rio de Janeiro, então capital federal) e o Museu Paulista (em São Paulo), eles incentivaram o avanço das pesquisas sobre a natureza no Brasil e desenvolveram certa visão patrimonial da natureza brasileira, ultrapassando em alguma medida os seus precedentes ao verem na natureza não só a utilidade econômica, mas também a fruição estética. Nesse grupo da Primeira República, são destacadas as atuações de Herman von Ihering, Alberto Loefgren, Edmundo Navarro de Andrade e Alberto Torres.

Alberto Torres (1865-1917), bastante conhecido na historiografia brasileira, nasceu em Itaboraí, no Estado do Rio de Janeiro. Foi jurista, pensador político e fez carreira política, sendo o seu último cargo, em 1901, o de ministro do Supremo Tribunal Federal. Escreveu O problema nacional brasileiro (1914), A organização nacional (1914) e As fontes da vida no Brasil (1915). Embora faça uma distinção entre esse autor e os outros cientistas mencionados, Franco considera que foi Torres quem contribuiu para a propagação de um discurso político-intelectual mais favorável ao debate em torno da proteção da natureza e do uso racional dos recursos naturais. Sobretudo, ele influenciou a geração posterior, que viria a se dedicar e aprofundar as questões colocadas pelo grupo aqui citado.

Alberto Torres defendia um projeto de nacionalidade que só poderia dar certo caso se espelhasse na gente e na natureza do país. De certo modo, criticava a modernidade imposta pelo industrialismo e a submissão do Brasil ao modelo de desenvolvimento proposto pelos países "adiantados", ambos prejudiciais à manutenção das riquezas naturais. Antecipando-se em 73 anos ao que viria a ser um dos pontos abordados pela "cartilha" do 
desenvolvimento sustentável, dizia que "A civilização tem o dever de conservar as riquezas inexploradas da Terra, reservas destinadas às gerações futuras, e de defender as que estão em produção, contra a exploração imprevidente, assim como o de proteger todas as raças e nacionalidades contra as formas de concorrência que possam importar ameaça a seus interesses vitais, bem como à segurança, propriedade $\mathrm{e}$ prosperidade de suas descendências" (TORRES apud FRANCO; DRUMMOND, 2004, p.156).

O pensamento de Torres, instando a elite intelectual e política a criar um projeto de nação compatível com o cientificismo e com o nacionalismo, ganhou ressonância no período em que o Brasil enfrentava a crise de abastecimento e financiamento decorrente da Primeira Guerra Mundial. Conforme Franco e Drummond (2004),

[...] esse papel da elite intelectual dependia não apenas de um papel proativo na construção das instituições políticas, mas na reforma profunda dos padrões de uso dos recursos naturais. Essa conexão do fortalecimento da nacionalidade com o uso prudente dos recursos naturais aproximava Torres daqueles cientistas que, um tanto mais esparsamente, se preocupavam com a proteção da natureza (FRANCO; DRUMMOND, 2004, p.159-60).

As ideias e as obras de Torres instigaram um grupo de cientistas naturais da geração seguinte, atuante entre as décadas de 1930 e 40, que deu continuidade às pesquisas sobre o mundo natural, demonstrou os danos causados pelo uso imprevidente dos recursos e, sobretudo, engajouse na ação de construir uma identidade nacional a partir da proteção da natureza.

Dentre os cientistas naturais dessa nova geração, que contribuíram para a inclusão da natureza no rol dos bens culturais e na incipiente, porém crescente formulação de políticas públicas ambientais, Franco destaca Alberto José de Sampaio, Armando Magalhães Corrêa, Cândido de Mello Leitão e Frederico Carlos Hoehne. Boa parte desse grupo era vinculada ao Museu Nacional do Rio de Janeiro.

Alberto Sampaio (1881-1946) nasceu em Campos, no Estado do Rio de Janeiro. Aos 24 anos de idade, fez concurso e assumiu o cargo de assistente de botânica no Museu Nacional, tornando-se, a partir de 1912, professorchefe. Estudou medicina, mas acabou dedicando-se à botânica. Integrou a comissão, liderada por Rondon, que foi ao Mato Grosso em 1916 e reuniu dados sobre a flora nativa levantados por pesquisadores nacionais e estrangeiros naquele estado. Essa viagem incentivou Sampaio a elaborar um mapeamento florístico de diversas regiões brasileiras. Em suas publicações, influenciado pelas ideias de José Bonifácio de Andrade e Silva e Alberto Torres quanto aos aspectos identitários da nação brasileira, pelos estudos de Navarro de Andrade e Loefgren sobre botânica e técnicas de reflorestamento, defendeu simultaneamente a proteção de áreas de florestas nativas, o incremento racional do reflorestamento para atender a uma sociedade urbanoindustrial em expansão e o estabelecimento de reservas naturais.

Franco identifica uma evolução do pensamento de Sampaio, ou melhor, uma reelaboração das suas ideias, o que se inicia por uma preocupação em implantar efetivamente o Serviço Florestal Federal, criado em 1921. Isso daria ao Brasil uma posição de destaque no mercado internacional de produtores de madeiras. Ao mesmo tempo, induziria um trabalho de pesquisa, controle e implementação de florestas econômicas, até a defesa cada vez mais intensa do estímulo aos mecanismos de interação do homem com a terra, vistos na sua totalidade como uma unidade orgânica. Para conscientizar a nação brasileira quanto ao valor do seu patrimônio natural, era necessária uma verdadeira cruzada educacional. Nas palavras do próprio autor, "a questão do Patrimônio Natural devia estar acima dos interesses particulares dos indivíduos. A natureza, erigida em utilidade pública e objeto de culto, teria a sua proteção motivada por objetivos que eram, ao mesmo tempo, econômicos, estéticos e sociais" (SAMPAIO apud FRANCO, 2002, p.71).

Armando Magalhães Corrêa (1889-1944) nasceu no Rio de Janeiro e, como Sampaio, foi professor do Museu Nacional. Não era um naturalista de formação e sim um escultor, desenhista e escritor. Como jornalista, atuando no Correio da Manhã, entre 1931 e 32 escreveu artigos que se transformaram no livro "O sertão carioca", publicado em 1933. Sob o título aparentemente paradoxal, essa obra analisava a região da cidade do Rio de Janeiro, compreendida entre os maciços da Tijuca e da Pedra Branca, e o vale de Jacarepaguá.

Segundo Corrêa, essas terras e as gentes que ali viviam careciam de uma mínima assistência do poder público. A sua análise recaía tanto sobre a exploração predatória dos recursos naturais quanto sobre as condições de vida dessa parte da população carioca. O que cabe ressaltar aqui é que Corrêa foi um entusiasta da criação de parques nacionais 
como forma de proteger a natureza, que, assim como para seus pares, era por ele considerada objeto de valor econômico, estético e identitário.

Cândido Firmino de Mello Leitão (1886-1948), nascido em Campina Grande, no estado da Paraíba, era formado em zoologia e professor do Museu Nacional, como Sampaio e Corrêa. De grande erudição e autor de notáveis obras sobre a história da biologia, contribuiu com estudos sobre a distribuição geográfica dos animais nas regiões brasileiras e a configuração de seus hábitats. Mas Mello Leitão, comparando sua tarefa à de Sampaio, considerava que o estudo da flora havia sido mais bem-sucedido no Brasil, dispondo-se de farta documentação, registrada por botânicos e geógrafos, diferentemente do que fizeram os "taxonomistas, mais preocupados, não raro, em contar escamas e transcrever dados alheios que em trazer sua pequena pedra para a construção de nossa zoogeografia" (LEITÃo apud FRANCO, 2002, p.174).

Mello Leitão foi também um defensor da criação de parques e reservas nacionais. Além de estar atento e participar, como os seus colegas do Museu Nacional, dos eventos e publicações científicos internacionais da época, os seus trabalhos tiveram o mérito de divulgar a importância da preservação da variedade de espécies da flora e da fauna. Elaborou, inclusive, um histórico dos parques e reservas existentes no planeta, o que contribuiu como exemplo e demonstração da importância da proteção das espécies faunísticas. Ele justificava as suas posições intelectuais em relação à conservação da natureza tendo como foco tanto o interesse econômico, científico e estético quanto o ético, pois, como zoólogo, entendia que os animais também têm direito à vida.

Tal como posteriormente se observa no conteúdo das cartas patrimoniais em âmbito internacional, os conservacionistas como Mello Leitão destacavam, no âmbito nacional, a importância do turismo como atividade econômica compatível com a conservação da natureza e como alternativa viável para manter os parques nacionais e as reservas naturais. Afinado com os seus conterrâneos, Leitão mesclava nos seus argumentos a proteção da flora e da fauna e as perspectivas de desenvolvimento econômico e social.

Frederico Hoehne (1882-1959), filho de alemães, nasceu em Juiz de Fora, Estado de Minas Gerais. De origem social humilde, concluiu apenas o ensino secundário na rede oficial. Aos 15 anos de idade, iniciou a sua vida de funcionário público como jardineiro-chefe do Museu Nacional do Rio de Janeiro. Autodidata, dedicou toda a sua vida a pesquisas na área de ciências naturais, interessandose principalmente por botânica, biogeografia e ecologia. Tornou-se um dos maiores especialistas em orquídeas no mundo. Em 1917, Hoehne mudou-se para São Paulo para trabalhar na Seção de Botânica do Instituto Butantã. Em 1938, assumiu o cargo de diretor-superintendente do Departamento de Botânica do Estado. Em 1942, tornou-se o primeiro diretor do Instituto de Botânica, no qual permaneceu por dez anos, até a sua aposentadoria. Ao longo de sua trajetória profissional, participou da Comissão Rondon e viajou por todas as regiões do Brasil, coletando material para a organização de herbários e a classificação da flora nativa. A sua produção acadêmica foi vasta. Publicou mais de uma centena de trabalhos científicos, quase quinhentos artigos em jornais e revistas, proferiu inúmeras palestras, conferências e cursos e editou quatro livros infantis. Por conta da sua vasta produção, foi homenageado diversas vezes e recebeu o título de doutor honoris causa, em 1929, pela Universidade de Göttingen, na Alemanha.

Nos seus textos, por diversas vezes Hoehne propôs a criação de estações biológicas e parques nacionais. Combinando as visões romântica e científica, bem ao gosto de alguns viajantes e naturalistas do século XIX, ele compreendia essas áreas de reserva do patrimônio natural como lugares de idílio e pesquisa, onde se conservasse algo da paisagem que não havia sido criada pelo homem (FRANCO, 2002, p.229). Embora nos anos 1930 fossem criadas algumas reservas naturais e estabelecida uma legislação nacional de proteção à natureza, Hoehne demonstrava descontentamento e preocupação com a falta de observância da lei. Mesmo quando chegou ao fim o Estado Novo, Hoehne continuou a defender a necessidade de uma identidade nacional baseada no sentimento patriótico e de respeito ao bem comum: somente por meio da educação e da legislação poderia a sociedade compreender e valorizar o patrimônio natural. A atuação firme do Estado e o comprometimento dos cidadãos eram fundamentais para tanto. Tal como os outros naturalistas do Museu Nacional do Rio de Janeiro, Hoehne entendia que os interesses individuais deviam ser subordinados aos da coletividade, e as ações presentes deveriam sempre ter em mente as consequências para as futuras gerações (FRANCO, 2002, p.255-6). 
O grupo de cientistas naturais pesquisados por Franco demonstra, de um lado, a importância do Museu Nacional do Rio de Janeiro, na época, como "principal centro de irradiação das ideias relativas à proteção da natureza"; de outro, a forte intenção de contribuir para a construção da nacionalidade brasileira, integrando natureza e homem ou, como se diria naquele tempo, com a integração entre as terras e as gentes do país. As posições ocupadas por esses estudiosos nas instituições públicas e o seu prestígio permitiram-lhes algumas vezes a aproximação com homens públicos que ocupavam posições estratégicas na vida nacional e podiam levar a cabo os seus projetos.

Além de todos eles serem ativos participantes de eventos nacionais e internacionais ligados à proteção da natureza e produzirem obras com circulação no ensino oficial e na imprensa local e nacional, lograram participar de momentos importantes da implementação de mecanismos legais de proteção ambiental. Sampaio (como representante do Museu Nacional do Rio de Janeiro), ao lado de Durval Ribeiro do Pinho (presidente da Sociedade dos Amigos das Árvores, criada em 1931), participou da elaboração do Código Florestal brasileiro. Magalhães Corrêa foi um dos fundadores da Sociedade dos Amigos de Alberto Torres, da qual eram membros as personalidades destacadas no cenário político da Era Vargas, como Oliveira Vianna, Juarez Távora e Plínio Salgado. Mello Leitão, além de ser professor no Museu Nacional, lecionava no Instituto de Educação do Rio de Janeiro, onde se tornou amigo de Fernando Azevedo, então responsável na instituição pelos projetos pedagógicos inovadores e editor da Coleção Brasiliana, da Companhia Editora Nacional, pela qual Mello Leitão publicou vários títulos. Hoehne tornou-se amigo de outra figura influente, Fernando Costa, que exerceu as funções de secretário de Agricultura, Indústria e Comércio do Estado de São Paulo, no governo de Júlio Prestes, e de ministro da Agricultura e interventor no estado de São Paulo durante a Era Vargas. Por meio de Fernando Costa, Hoehne obteve influência em âmbito federal para que se estabelecessem os primeiros parques brasileiros e no Estado de São Paulo obteve apoio para organizar o Instituto de Botânica e o Jardim Botânico.

A coesão desse grupo e a sintonia com o projeto modernizador do Governo Vargas propiciou a concretização de alguns estudos e pesquisas relacionados à criação de áreas de proteção ao longo das décadas de 1930 e 40 . No entanto, o projeto político que se tornou hegemônico nesse período priorizou, sobretudo, o crescimento econômico, em detrimento da proteção da natureza, explorada como recurso lucrativo seja pela iniciativa privada, seja pelo Estado.

Embora continuasse a exploração indiscriminada dos recursos naturais no decorrer da consolidação da República e os intelectuais sensíveis à contínua devastação do mundo natural vissem seus esforços de perpetuação de espécies vegetais e animais perderem terreno para os interesses exclusivamente econômicos, várias entidades civis e instituições oficiais foram criadas a fim de proteger a natureza ou evitar a sua total degradação.

\section{A criação de entidades em defesa da conservação da natureza}

Dentre as primeiras instituições organizadas pela sociedade civil que contribuíram para sensibilizar a sociedade brasileira e mobilizar setores públicos para a necessidade de proteger a natureza, destacam-se as entidades conservacionistas Sociedade dos Amigos das Árvores, a Associação de Defesa do Meio Ambiente de São Paulo (Ademasp), a Fundação Brasileira para a Conservação da Natureza (FBCN) e a já citada Sociedade dos Amigos de Alberto Torres. A Sociedade dos Amigos das Árvores foi fundada em 1931, em São Paulo, por Alberto Sampaio, que em 1934 viabilizou, com o apoio do Museu Nacional do Rio de Janeiro e o patrocínio do chefe do governo provisório, Getúlio Vargas, a realização da Primeira Conferência Brasileira de Proteção à Natureza, no Rio de Janeiro.

Conforme a análise de Franco, esse evento demonstrou que havia um grupo relativamente organizado em torno de preocupações com a conservação da natureza e que as suas ideias tinham certa ressonância na formação da opinião pública e nas ações das autoridades públicas. Mais do que isso, as ideias desse grupo estavam fortemente influenciadas e concatenadas com as correntes de pensamento e as ações desenvolvidas em outros países na mesma época, sendo que os argumentos que justificavam salvaguardar o mundo natural "[...] oscilaram entre uma perspectiva mais pragmática, voltada para a conservação dos recursos naturais, e outra de caráter mais estético, voltada para a preservação de áreas valorizadas pela sua beleza selvagem" (FRANCO, 2002, p.38).

Ainda dentre as ações locais, voltadas para a proteção da natureza, em São Paulo foi estabelecida, em 
1953, a Associação de Defesa da Flora e da Fauna. Ela foi criada depois de intensos conflitos relacionados ao uso das matas do Pontal do Paranapanema, constituídas por cerca de 150 mil hectares de terras públicas invadidas por grileiros que destruíram $80 \%$ dessa floresta. Na década de 1970, seu nome foi mudado para Associação de Defesa do Meio Ambiente e, atualmente, por conta de diversas outras associações homônimas, mudou novamente para Associação de Defesa do Meio Ambiente de São Paulo (Ademasp). Criada por jovens estudantes - entre eles Paulo Nogueira-Neto (1922), que se tornaria daí por diante um ativo ambientalista -, essa associação apresentava como objetivo inicial lutar pela criação de uma reserva florestal pública no Pontal do Paranapanema, visando a proteger o que ainda restava das florestas invadidas (URBAN, 1998, p.88).

Já a FBCN, fundada em 1958, no Rio de Janeiro, resultou dos vínculos que os cientistas brasileiros mantinham com o movimento conservacionista internacional. Fortemente influenciada pela IUCN, a instituição brasileira criou, em 1966, comissões técnicas nos mesmos moldes da instituição internacional: Comissão Técnica de Educação, Comissão Técnica de Legislação, Comissão Técnica de Parques Nacionais e Reservas Afins, Comissão Técnica de Ecologia e Comissão Técnica de Espécies Raras e Ameaçadas de Extinção.

Todavia, a criação dessas entidades conservacionistas e a sua preocupação em sensibilizar autoridades e influenciar no estabelecimento de políticas voltadas para a conservação da natureza ainda dependeriam de articulações políticas, discussão científica e ampliação dos conhecimentos sobre o que conservar e como conservar.

\section{Considerações finais}

A história da ocupação do território brasileiro pelos europeus e a posterior formação da nação brasileira na virada do século XIX para o XX revela, desde o seu início, a constante tensão entre duas ideias de natureza: uma voltada a atender aos interesses econômicos de exploração e apropriação em larga escala da diversidade de espécies da fauna e da flora tropicais; e a outra, ainda que constituída por manifestações isoladas - porém crescentes e oriundas de vários setores da sociedade e do Estado -, em favor da proteção e da conservação dos ambientes naturais.
Todavia, muitas vezes tais empreitadas em prol da conservação da natureza foram solapadas pelas descontinuidades político-administrativas e a intervenção sub-reptícia dos interesses privados, tendo que esperar até a década de 1930 para que começasse a tomar forma constitucional e institucional. Pode-se dizer que, até o início do século $\mathrm{XX}$, as tentativas formais e informais de proteção à natureza em território brasileiro eram tão esparsas e inférteis quanto iam se tornando as próprias matas brasileiras com o extrativismo desordenado e as extensas plantações de cana-de-açúcar, café e algodão. Basta dizer que a Constituição Brasileira, discutida durante o ano de 1890 e promulgada em fevereiro de 1891, não fazia qualquer alusão à proteção da natureza. Ela se inspirou nos princípios liberais e democráticos da Constituição dos Estados Unidos da América, mas suprimiu vários deles para atender aos interesses e pressões das oligarquias latifuindiárias. A Constituição Brasileira promulgada em julho de 1934, por sua vez, inspirada na Carta de Weimar, apresentava um capítulo sobre a ordem econômica e social. A natureza, percebida ainda e tão-somente sob o viés econômico e utilitarista, adentrava no artigo 119 , referente ao aproveitamento industrial dos recursos naturais, o que nacionalizaria progressivamente as minas, as jazidas minerais e as quedas d'água.

Embora nada fosse dito na Constituição de 1934 a respeito da natureza como objeto de proteção nacional, havia sido editado poucos meses antes, em janeiro do mesmo ano, finalmente, o Código Florestal. Este era um instrumento legal e normativo de proteção às florestas existentes no território nacional. Nesse Código a flora passava a ser, sobretudo, considerada formalmente um bem de interesse comum a todos os habitantes do país.

Pode-se inferir que as malogradas tentativas de intervir no crescente processo de devastação da natureza brasileira esbarravam não apenas no fato de as autoridades públicas e a elite econômica no seu conjunto não vislumbrarem a abrangência dos riscos ecológicos da época em que viviam como também no fato de que o processo de consolidação do Estado brasileiro mal se esboçara. Esse processo, junto com as ideias de nação e identidade, seria elemento fundamental tanto para a futura definição do patrimônio natural brasileiro como para a constatação cultural de que os riscos ecológicos exigiam o estabelecimento de instituições e ações para contê-los ou preveni-los. 


\section{Referências}

A CARTA, de Pero Vaz de Caminha. Edição de base: Carta a El Rei D. Manuel. São Paulo: Dominus, 1963.

BIGG-WHITER, T. P. Novo caminho no Brasil Meridional: a província do Paraná, três anos de vida em suas florestas e campos (1872-1875). Rio de Janeiro: José Olympio; Curitiba: Universidade Federal do Paraná, 1974.

BRETON, S. Cristianismo e o conceito de natureza. In: BOURG, D. Os sentimentos da natureza: Lisboa: Perspectivas Ecológicas, 1997.

COSTA, M. de F.; DIENER, P. Viajando nos bastidores: documentos da viagem da Expedição Langsdorff. Cuiabá: Ed. UFMT, 1995.

DAMATTA, R. Em torno da representação da natureza no Brasil: pensamentos, fantasias e divagações. In: BOURG, D. Os sentimentos da natureza. Lisboa: Perspectivas ecológicas, p.128-129, 1997.

DEAN, W. A ferro e fogo: a história da devastação da mata atlântica brasileira. São Paulo: Companhia das Letras, 1997.

DRUMMOND, J. A. Ciência socioambiental: notas sobre uma abordagem necessariamente eclética. In: ROLIM, R. C.; PELLEGRINI, S. R.; DIAS, R. História, espaço e meio ambiente. Maringá: ANPUH/PR, p.14-15, 2000.

FOUCAULT, M. As palavras e as coisas: uma arqueologia das ciências humanas. 3. ed. São Paulo: Martins Fontes, 1985.

FRANCO, J. L. de A. proteção à natureza e identidade nacional: 1930-1940. Tese (Doutorado em História) Universidade de Brasília, 2002.

FRANCO, J. L. de A.; DRUMMOND, J. A. Preocupações com a proteção à natureza e com o uso dos recursos naturais na Primeira República brasileira. Textos de História, v. 12, n. 1/2, 2004.

GIDDENS, A. Para além da esquerda e da direita: o futuro da política radical. São Paulo: Editora da Universidade Estadual Paulista, p. 21, 1996.

HOLANDA, S. B. de. Raizes do Brasil. 26. ed. São Paulo: Companhia das Letras, 1995.

LISBOA, K. M. Viagem pelo Brasil de Spix e Martius: quadros da natureza e esboços de uma civilização. Revista Brasileira de História, v. 15, n. 29, p. 73-91, 1995.

PÁDUA, J. A. A profecia dos desertos da Líbia: conservação da natureza e construção nacional no pensamento de José Bonifácio. Revista Brasileira de Ciências Sociais, v. 15, n. 44, 2000.

. O sopro da destruição: pensamento político e crítica ambiental no Brasil escravagista (1786-1888). Rio de Janeiro: Jorge Zahar, 2002.

ROUANET, S. P. Mal estar na modernidade: ensaios. São Paulo: Companhia da Letras, 1993.

SPIX, J. B. von; MARTIUS, K. F. P. von. Viagem pelo Brasil: 1817-1820. 3. ed. São Paulo: Melhoramentos; Brasília: INL, 1976.

THOMAS, K. O homem e o mundo natural: mudanças de atitude em relação às plantas e aos animais (1500-1800).

URBAN, T. Saudade do matão: relembrando a história da conservação da natureza do Brasil. Curitiba: Editora da UFPR; Fundação O Boticário de Proteção à Natureza; Fundação MacArthur, 1998. 